\title{
PERCURSOS HISTÓRICOS E PAISAGENS CULTURAIS: O LEGADO DOS IMIGRANTES EM SANTA CATARINA
}

\author{
Margareth de Castro Afeche Pimenta \\ Universidade Federal de Santa Catarina \\ pimenta.margareth@gmail.com
}

\begin{abstract}
RESUMO
O conceito de paisagem cultural foi recentemente inserido no Brasil, a partir da chancela do IPHAN em 2009. A ampliação do olhar frente à preservação patrimonial - do objeto arquitetônico ao espaço urbano ou regional - faz-se acompanhar da preocupação em assimilar os aspectos culturais ao ambiente. Compreendendo paisagem como natureza transformada pela ação humana, aproxima, pela primeira vez, preservação ambiental e cultural. A proteção conjunta de paisagens e práticas sociais pode contribuir, também, para estimular a preservação de comunidades que são frágeis economicamente, mas ricas em termos culturais. Esse ensaio pretende contribuir para esse debate a partir da realidade catarinense, constituída, historicamente, por sucessivas frentes migratórias europeias que, a partir do domínio das técnicas, moldaram o ambiente, e legaram um rico repertório de paisagens culturais complexas e variadas.
\end{abstract}

Palavras-chave: Paisagem cultural. Santa Catarina. Migrações. Ambiente. Cultura.

\section{HISTORICAL PATHWAYS AND CULTURAL LANDSCAPES: THE LEGACY OF SANTA CATARINA IMMIGRANTS}

\begin{abstract}
The concept of cultural landscape has been recently inserted in Brazil, with IPHAN's seal in 2009. The widening of the preserving heritage view - from the architectural object to the urban or regional space - has been accompanied by the concern to assimilate cultural aspects to environment. Understanding landscape as the nature transformed by the human actions, this conception approximates, for the first time, environmental and cultural preservation. The combined protection of landscapes and social practices may also contribute to stimulate the preservation of communities that are economically fragile, but rich in cultural terms. This essay intends to contribute with some ideas to this debate, taking Santa Catarina as an example that has been constituted, historically, by successive European migratory fronts. Through the mastery of techniques, these migrants have shaped the environment as well as created a rich repertoire of complex and varied cultural landscapes.
\end{abstract}

Keywords: Cultural landscape. Santa Catarina. Migration. Environment. Culture.

\section{INTRODUÇÃO}

Apesar do conceito de paisagem cultural ter sido definido pela UNESCO em 1992, no Brasil, ele somente vai ser incorporado como política patrimonial, pela chancela do IPHAN, em 30 de abril de 2009. Constitui-se, então, em uma discussão relativamente recente e, por isso, merece atenção especial, ainda mais pelas possibilidades que apresenta de integração de diversas áreas do conhecimento na preservação das heranças históricas, quer sejam culturais ou ambientais. Acompanhando a ampliação escalar da análise preservacionista - do objeto arquitetônico isolado ao

$\begin{array}{llllll}\text { Caminhos de Geografia } & \text { Uberlândia - MG } & \text { v. 19, n. } 67 & \text { Set/2018 } & \text { p. 126-142 } & \text { Página } 126\end{array}$


espaço urbano ou rural -, os objetivos materiais também passam a ser considerados conjuntamente com as práticas e as atitudes sociais, ou seja, com a incorporação do patrimônio imaterial como elemento relevante para valorização cultural. A paisagem cultural, tal qual definida pelo Artigo $1^{\circ}$ da Convenção da UNESCO em 1992, refere-se às "obras combinadas da natureza e dos homens", registro de diversas épocas que significam as relações estabelecidas entre homem e natureza, mediadas pelas técnicas, elaborando, conjuntamente, suas representações. Ela é testemunho, registro de diversas épocas que podem ser presenciadas no momento atual, que significam a forma de apropriação da natureza pelo homem, com suas técnicas e suas representações. (UNESCO, 2010) É um conceito que aproxima as preservações ambiental e cultural, concebendo-as como um todo indissolúvel. Aqui reside o seu grande aporte de potencial preservacionista. A paisagem cultural é a fusão do ambiente com a vida que o anima.

O conceito de paisagem cultural parece atribuir, então, ao lugar um papel proeminente, pois este demonstra ser capaz de constituir-se em realizador da síntese entre elementos materiais e imateriais da cultura. O lugar é onde se consolida a integração entre as práticas e as paisagens. Lá o homem molda o cenário em que se insere e nele interpreta diversos papéis, tornando-se fundamentais as interferências de proximidade, ou seja, as relações diretas com o outro. Além de alguns interesses similares e das vivências compartilhadas, os olhares divergentes podem permitir o enriquecimento da elaboração e da compreensão da vida que se realiza. (ARENDT, 2009) O lugar é o espaço do acontecimento, do dia-a-dia, das conexões interpessoais, dos encontros. (SANTOS, 1996) Sua preservação, ou sua herança, permite constituir uma história particular no decorrer do fluxo temporal, sem linearidade, mas com a sua reconstituição constante, atribuindo-lhe novas significações. A memória materializada ou transmitida oralmente desempenha um papel de reconhecimento histórico. (JEUDY, 1990) As permanências deveriam ser, portanto, valorizadas, substituindo a razão econômica pela social. (BABELON; CHASTEL, 1994) A paisagem, que possui a virtualidade de reter a ideia do passado, quando concebida como paisagem cultural passa a considerar não somente os objetos construídos como o foco da preservação, mas todo o seu contexto de inserção, amalgamando as ações, os processos e o produto do trabalho, o patrimônio cultural ao ambiental. Permite a valorização das atitudes sociais na confecção do ambiente no perpassar dos processos históricos. (PIMENTA, 2015)

Faz-se necessário, assim, reconstruir o olhar, sob a ótica dessas novas possibilidades de análise do lugar e suas paisagens como síntese do fazer simbólico (CASSIRER, 1998), no sentido de buscar preservar as condições de vida de populações no ambiente em que vem se inserindo historicamente, com suas especificidades culturais. (GOETHE, 1863; PIMENTA, 2016) Este artigo pretende, então, ser um ensaio nesse sentido, pensando o estado de Santa Catarina como um todo, a partir de suas especificidades culturais, o que poderia permitir, com o decorrer dos debates, a criação de critérios mais precisos de configuração de suas paisagens culturais. Por colidir diretamente contra potentes interesses econômicos, a paisagem cultural está sendo postergada como política pública, o que não diminui sua importância, que reside, precisamente, em salvaguardar o significado histórico de áreas que, apesar de seu valor patrimonial, se encontram cada vez mais ameaçadas. Santa Catarina apresenta uma riqueza paisagística muito peculiar que se identifica, claramente, com os diversos processos de ocupação regionais e urbanos, amálgamas entre os saberes-fazeres trazidos dos países de origem de seus imigrantes, em sua maior parte europeus, e um território, até então, totalmente estranho e inabitual.

O estado catarinense foi construído por sucessivas levas migratórias, conformando paisagens diversificadas, constituídas ao longo dos itinerários onde foram se estabelecendo populações de diferentes etnias em subsequentes períodos históricos. Pequenas economias ancoradas regionalmente - muitas delas crescendo exponencialmente a partir de bases modestas - permitiram a expressão de formas urbanas e arquitetônicas amparadas em tradições culturais populares, resultantes de adaptações às condições locais e à lógica de novas relações territoriais em processo de constituição. Das ocupações litorâneas e caminhos de tropas setecentistas às colônias de imigração do século XIX e XX, um rico patrimônio cultural, existente ou desaparecido, deve ser melhor conhecido, valorizado e preservado.

Em Santa Catarina, cada lugar tem sua história própria, uma história menor, sem suntuosidade, modesta. Pensá-la talvez suponha o reconhecimento dessas características particulares, o que pode permitir a sistematização das informações de forma a torná-las compreensíveis dentro de uma coerência totalizadora. (MARX, 2007) Se o lugar pode ser considerado como síntese de múltiplas determinações, então, resta the atribuir o papel de suporte para a análise da interconexão dos seus diversos componentes, do sensível capaz de permitir a conectividade do conjunto de conceitos,

$\begin{array}{llllll}\text { Caminhos de Geografia } & \text { Uberlândia - MG } & \text { v. 19, n. } 67 & \text { Set/2018 } & \text { p. 126-142 } & \text { Página } 127\end{array}$


indispensáveis à compreensão do real. (SANTOS, 1985; LEFÈBVRE, 1974). A unicidade dos lugares está registrada em suas paisagens culturais singulares. De localidade em localidade, reconhecendo as impressões deixadas, torna-se factível a reconstituição das histórias dessas populações, suas práticas e sua apropriação ambiental, feita a partir de técnicas tradicionais que foram adaptadas e transformadas de forma engenhosa. Esses registros são detentores de aspectos das culturas locais e de marcações históricas que deveriam significar a possibilidade de reconstituição das lembranças de um passado ativo, aquele cunhado pelas ações dos homens comuns no processo de restituição dos ciclos da vida.

\section{CARACTERÍSTICAS CULTURAIS DAS REGIÕES CATARINENSES}

Santa Catarina compõe-se de múltiplas regiões culturais, que tiveram seus processos de formação baseados na acumulação de pequenos capitais. São migrantes vindos da Europa que adaptaram, de maneira inventiva, técnicas e conhecimentos adquiridos a um meio diverso daquele no qual se inseriam no país de origem. (WILHEMS, 1980) Poder-se-ia dizer que, ao longo de sua história, foram se formando pequenas centralidades locais, solidarizando, com o tempo, as redes regionais (BOUDEVILLE, 1963), que coincidem, de forma imperfeita, com os processos de ocupação, reforçando as características particulares das diferentes áreas do Estado. Os diversos lugares, assim constituídos, acabam, então, impregnados pelos objetos e ações (SANTOS, 1996) que se desenvolveram a partir desses fluxos migratórios, criando culturas e paisagens reconhecíveis ao visitante de passagem. As povoações podem ser claramente diferenciadas por suas características peculiares. Os elementos homogeneizantes em suas paisagens conferem-lhes uma harmonização de conjunto, mas, ao mesmo tempo, as distinguem das demais conformações urbanas ou regionais. As composições heterogêneas entre ambiente natural e construído foram cunhadas pelos traços culturais dos migrantes que transplantaram, com adequações, seus saberes tradicionais e suas práticas originárias.

Em Santa Catarina, os lugares constituíram-se historicamente, suas peculiaridades estão irreversivelmente ligadas ao passado multicultural trazido pelas diversas nacionalidades europeias. Diferentemente de outras regiões do país, não houve, aqui, grandes ciclos econômicos que the atribuíssem características relativamente hegemônicas, que pudessem resultar em espaços de suntuosidade e deixassem registros ostentatórios. (VEBLEN, 1978) São sempre pequenas comunidades que construíram, lentamente, com técnicas muitas vezes rudimentares, uma herança simples e despojada, mas culturalmente rica e multifacetada. Em alguns lugares, houve características culturais dominantes; em outros, vigora a composição, quase caleidoscópica, de muitas diferenciações. Da leitura de suas próprias trajetórias pode ser extraída a proposta metodológica para as análises que devem preceder as chancelas das paisagens culturais específicas: acompanhando os passos históricos dos migrantes europeus que imprimiram marcas diversas, a partir da transformação da natureza pelo seu trabalho, acomodando às condições encontradas, procedimentos técnicos adquiridos no país longínquo. As heranças culturais impregnam, assim, os diferentes lugares, atribuindo-Ihes características peculiares, tanto como elementos da paisagem, como em relações e construções simbólicas. (CLAVAL, 1999) Preservar somente a forma das edificações, sem observar as comunidades que residem ainda nesses lugares, é esquecer que várias técnicas e meios utilizados para a reprodução da vida ainda estão, muitas vezes, presentes. Ambiente e cultura, pensados conjuntamente, poderiam se constituir em alternativas de desenvolvimento menos embrutecedoras.

Em Santa Catarina, os lugares constituíram-se historicamente, marcando a paisagem de um legado singelo (inclusive arquitetônico e urbanístico), que acompanhou os sucessivos ciclos produtivos em suas diferentes localidades a partir da introdução de migrantes de culturas as mais variadas. Aqui se apresenta, então, o roteiro pelo qual o reconhecimento do valor patrimonial da paisagem cultural deve seguir: acompanhando os passos históricos dos migrantes europeus que imprimiram marcas diversas, a partir da transformação da natureza pelo seu trabalho, adaptando, ao meio local, um saber-fazer trazido do país de origem. Deve-se atribuir ao lugar o papel de preservação da cultura das diversas correntes migratórias, sem priorizar, no entanto, a atratividade turística em detrimento da autenticidade e da permanência das comunidades tradicionais. Duas alternativas podem, ainda, estar colocadas: o desenvolvimento socioeconômico de modelo europeu, onde o turismo é atraído, sem significar a descaracterização dos lugares, ou a continuidade dos procedimentos brasileiros, onde a adulteração das áreas de valor patrimonial faz-se de forma desmesurada, para o agrado e a animação de turistas, em geral, pouco informados.

$\begin{array}{llllll}\text { Caminhos de Geografia } & \text { Uberlândia - MG } & \text { v. 19, n. } 67 & \text { Set/2018 } & \text { p. 126-142 Página } 128\end{array}$


Figura 1: Santa Catarina e suas regiões culturais de imigração

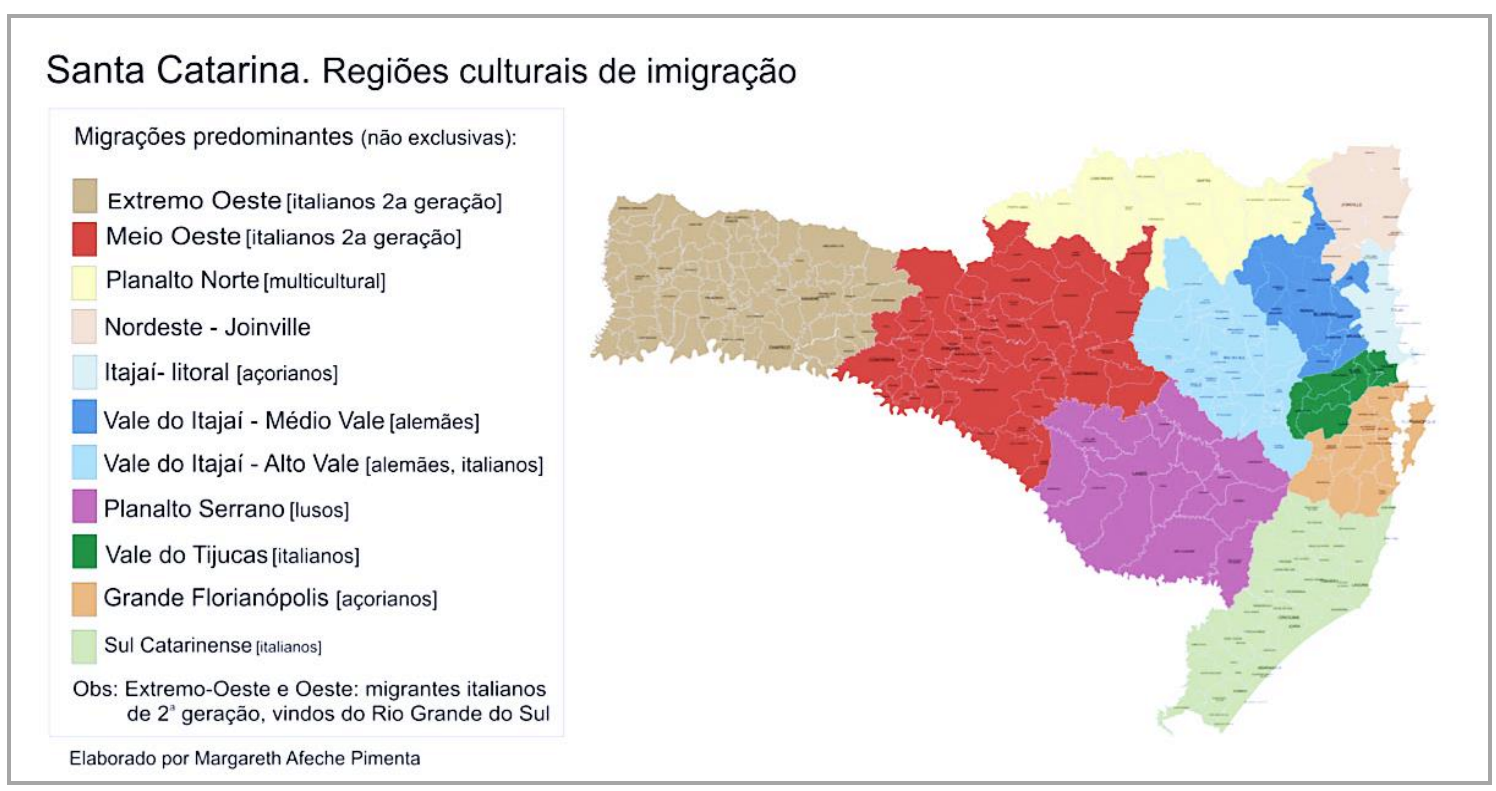

Fonte: Elaborado pela autora, a partir de base cartográfica do IBGE.

Em Santa Catarina (SC), sucessivas levas de migrantes de diferentes nacionalidades ocuparam primeiro o litoral e foram, posteriormente, em direção ao interior, percorrendo os vales dos rios, instalando pequenas colônias que mantiveram traços culturais perceptíveis, até o momento, nas suas paisagens. (Fig. 1) Da defesa da costa seguem-se os pequenos povoamentos litorâneos, baseados na pequena produção de subsistência com pouca troca comercial. A partir de meados do século XIX, inicia-se o processo de interiorização. Percorrendo os fundos dos vales dos rios, migrantes de diversas nacionalidades, vindos, em geral, de áreas industrializadas, vão se apropriando do ambiente e construindo paisagens. Com o domínio das técnicas construtivas, elaboram um rico legado arquitetônico, altamente marcado pelas heranças históricas. Suas construções formam conjuntos rurais ou urbanos, implantados de forma a permitir o desempenho das atividades econômicas e sociais. Os rios são, certamente, fonte de energia e de abastecimento, assim como de escoamento dos produtos. São, também, parte da reprodução dos sítios conhecidos, como no caso dos alemães, com os vales encaixados em meio às colinas circundantes. Indo do litoral até o planalto central, esses migrantes de primeira geração conformaram paisagens inigualáveis, distintas entre si, mas profundamente cunhadas de signos culturais predominantes.

\section{AÇORIANOS NO LITORAL, PORTUGUESES NO PLANALTO SERRANO}

O século XVI já recebe navegadores que aportam nas costas catarinenses, principalmente na llha de Santa Catarina e na Baía de Babitonga, que foram os locais mais visitados. Portugueses e espanhóis faziam ponto de parada, nestas terras, em suas rotas de navegação que tinham por destino o Rio da Prata. Portugal, visando consolidar seus domínios, promoveu, então, o alargamento de seu território a partir das bandeiras, provenientes da Capitania de São Vicente. O litoral catarinense passou a ser percorrido e conhecido, então, por bandeirantes, crescendo o interesse pela sua posse e ocupação. (CABRAL, 1972)

Santa Catarina teve, assim, seu processo de ocupação determinado pela sua localização em relação à defesa territorial e à aguada dos navios que aqui aportavam. Navegantes de várias nacionalidades (franceses e espanhóis, principalmente) que visavam tomar posse do Brasil meridional, visitavam a costa, trazendo insegurança quanto a sua possessão. A função de defesa passa a ser prioritária e deixa uma rica arquitetura de fortalezas, que se concentram, principalmente, nos arredores da llha de Santa Catarina. Patrimônio precocemente reconhecido, já constando do Livro do Tombo de 1938, as fortalezas de Santo Antônio de Ratones; São José da Ponta Grossa e o Forte Santana (em Florianópolis), assim como a Fortaleza de Santa Cruz de Anhatomirim (em Governador Celso Ramos), faziam parte do mesmo sistema defensivo.

$\begin{array}{llllll}\text { Caminhos de Geografia } & \text { Uberlândia - MG } & \text { v. 19, n. } 67 & \text { Set/2018 } & \text { p. 126-142 } & \text { Página } 129\end{array}$


Por sua situação geográfica privilegiada em relação à rota do Prata e seu sítio propício à atividade defensiva, as costas litorâneas receberam os primeiros povoamentos no século XVII, que tiveram início com a fundação de São Francisco do Sul (1658), seguindo com a criação de Nossa Senhora do Desterro (1672) e, posteriormente, de Laguna (1684). Esses núcleos viviam quase exclusivamente de atividades de subsistência, praticando uma agricultura rudimentar e a pesca artesanal. No início do século XVIII, Laguna, apesar de se caracterizar ainda como um pequeno lugarejo, constituía-se como o mais importante núcleo da costa catarinense, exportando peixe seco para Santos e Rio de Janeiro. (CABRAL, 1970)

Figura 2: Centro Histórico de São Francisco do Sul e de Laguna

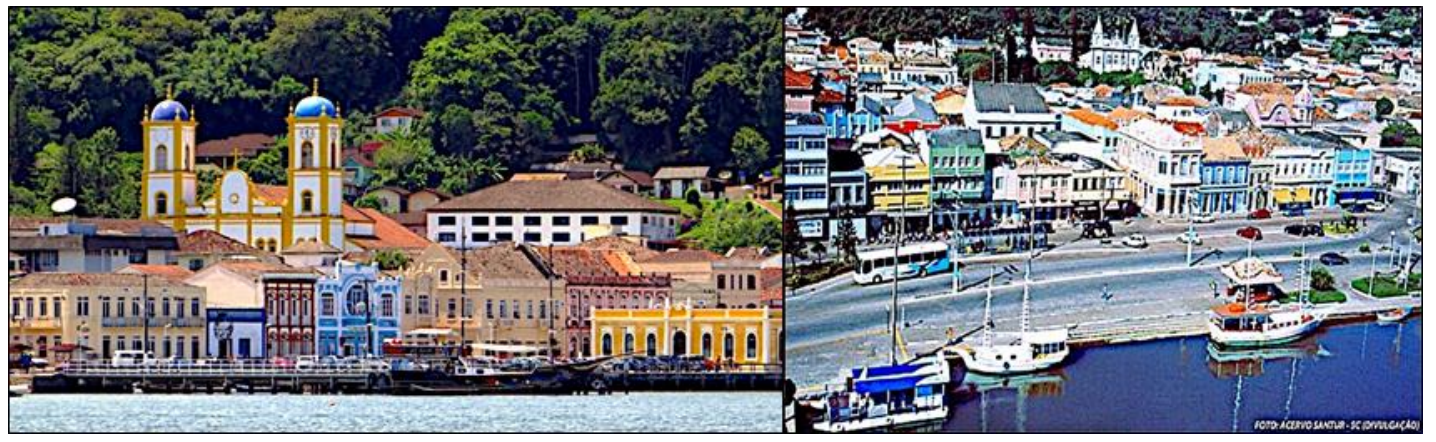

Fontes: BERTOLDI, 2017; SC. Secretaria de Turismo, Cultura e Esporte, 2017.

Procurando estabelecer um processo de ocupação mais efetivo no sentido de garantir a territorialidade portuguesa, esses primeiros núcleos litorâneos catarinenses receberam, em meados do século XVIII, novos fluxos migratórios açorianos, que acabam configurando a tipologia e a morfologia urbanas. São pequenas nucleações, organizadas em torno da praça cívica e religiosa, com traçado irregularmente ortogonal, em geral acomodado à topografia. (REIS FILHO, 1968) As casas em fita, com telhados que se inclinam para a rua, constroem um conjunto harmônico e solidário, que define os limites dos espaços públicos abertos. (BROOS, 2002). Desses núcleos açorianos, somente recentemente as cidades de Laguna (1985) e São Francisco do Sul (1987) tiveram seus sítios tombados pelo IPHAN. (Fig. 2) Alguns poucos bens isolados em Biguaçu e Florianópolis complementam o acervo tombado, pelo IPHAN, da herança luso-brasileira catarinense. (IPHAN, 2017)

As pequenas aglomerações que se dispersaram ao longo da llha de Santa Catarina organizavam-se como colônias agrícolas e pesqueiras, que associavam certos rituais às ações de sobrevivência, deixando, assim, com o passar do tempo, várias práticas e manifestações culturais, que continuam ativas no seio das populações locais. Os eventos religiosos e as festas, combinavam-se com as atividades artesanais, configurando paisagens bem características, originárias da cultura açoriana. (PIMENTA, 2014) Grande parte dessas povoações foram desorganizadas pela voracidade da atividade turístico-imobiliária, principalmente, a partir da década de 1980. Quando expulsas da orla marítima, as colônias pesqueiras desarticulam-se, fazendo desaparecer, também, as rendas de bilro, as cerâmicas, as farinhas artesanais de mandioca e numerosos outros produtos que constituíam o sistema produtivo dessa organização societária. Algumas dessas atividades ainda persistem em poucos locais, inclusive como meio de subsistência, adquirindo sempre características de resistência, frente às ameaçadas de desarticulação de suas relações comunitárias. Alguns exemplos, entre tantos, podem ser retirados da pescaria. Quando chegam os barcos, todos os que assim quiserem participam do arrastão, ganhando, por isso, uma participação nos resultados da pesca. O próprio ato preparatório, como a confecção das redes e a organização da atividade são efetuadas, ao ar livre, reunindo membros da população local. (Fig. 3 e 4) 
Figuras 3 e 4: A prática do arrastão (à esquerda) e a comunidade pesqueira da Barra da Lagoa em Florianópolis (SC)

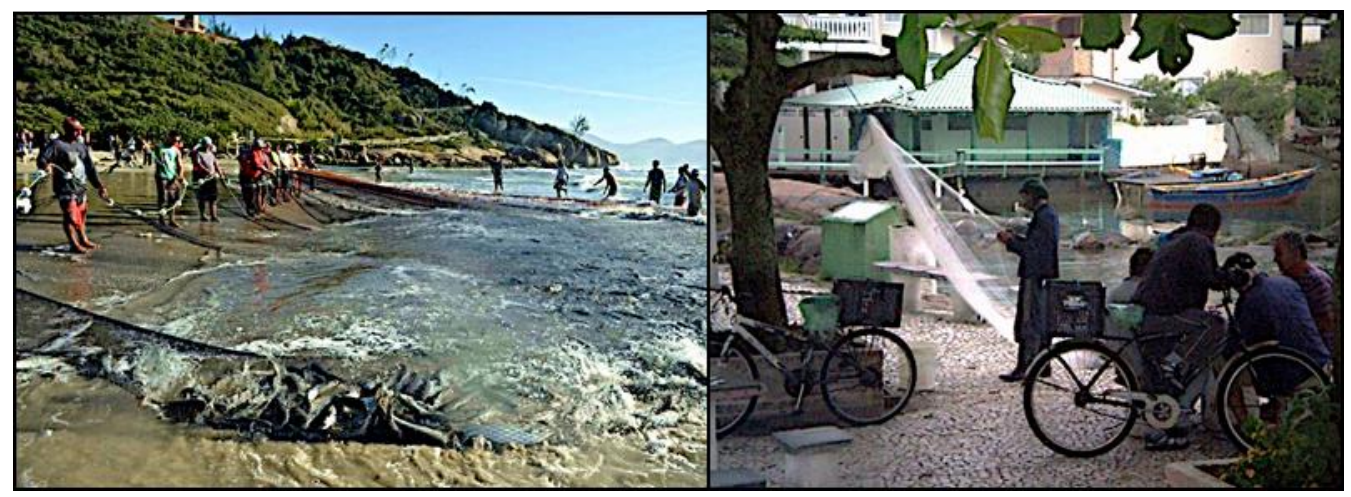

Fontes: Diário Catarinense (DC), 13/06/2012; foto de Clementina Neves, 2009.

Os portugueses marcam, também o processo de ocupação do Planalto serrano, cujas povoações se constituem como resultado do estabelecimento de pontos de paragem para o caminho das tropas que se deslocavam do Rio Grande do Sul para São Paulo. (LOCKS, 2006) A arquitetura luso-brasileira, assim como as práticas sociais e a organização da estrutura urbana tradicional deveriam ser, certamente, objeto de uma valorização mais sistemática que permitisse uma tomada de consciência social de sua importância para a identidade catarinense. (PELUSO JR., 1991) Os saberes-fazeres dos mestres artesãos locais marcaram as construções religiosas, residenciais e comerciais, assim como deixaram, ainda, sobretudo no planalto, ricos trabalhos em cantaria, cujo técnica ainda permanece sendo utilizada. (PIMENTA et al., 2012) Há, assim, formas tradicionais de vida que se reproduzem principalmente no meio rural, o que permite práticas sociais e relações comunitárias no exercício da confecção de suas paisagens.

\section{COLÔNIAS ALEMÃS DIFUNDEM-SE PELOS FUNDOS DE VALES}

A vinda de alemães para o Brasil foi incentivada pelo Imperador Dom Pedro I, que pretendia povoar o Brasil meridional. A imigração alemã em Santa Catarina iniciou-se em 1829, quando 523 alemães, oriundos de Bremen, fundaram a colônia São Pedro de Alcântara. Parte deles, desloca-se para o Vale do Itajaí em 1835, iniciando sua ocupação a partir da cidade de Gaspar. Outras colônias alemãs foram criadas no Estado, destacando-se as de Blumenau (1850) e Brusque (1860) nos vales dos Rios Itajaí-Açu e Itajaí-Mirim, e a colônia Dona Francisca (hoje Joinville), que se instalou, em 1851, na Baía de Babitonga, às margens do Rio Cachoeira e nas proximidades da antiga colônia açoriana de São Francisco do Sul. (CABRAL, 1970)

Blumenau é fruto da concessão de terras pelo Governo Provincial ao Dr. Hermann Bruno Otto Blumenau que pretendia ali criar uma colônia agrícola, seguindo modelos utópicos europeus de meados do século passado. (FOUQUET, 1950) A partir de 1852 será efetuada a repartição dos 12 primeiros lotes, construída a primeira igreja e montado o barracão de madeira para hospedagem provisória dos imigrantes, marcando, assim, a fundação da colônia. (SEIFFERT, 1974) A colonização espalhou-se rapidamente. Partindo das embocaduras do rio Garcia e do Ribeirão da Velha, chegou a alcançar uma extensão aproximada de $11.000 \mathrm{~km}^{2}$, correspondente aos atuais municípios de Gaspar, Indaial (1859), Timbó (1869) e Ibirama (1897), desmembrados, em 1935, de Blumenau que permaneceu com $1.160 \mathrm{~km}^{2}$, incluindo os distritos de Massaranduba (1870) e Rio do Testo. Enquanto nas áreas de Brusque e Luís Alves a ocupação era limitada pelas características do relevo, as condições na bacia do Itajaí-Açu a montante de Blumenau, eram bastante favoráveis à colonização. (PELUSO JR., 1950). Até 1860, Blumenau contava com 947 habitantes. Em 1890, fase de encerramento do movimento migratório, já havia recebido em torno de 20.000 imigrantes. (SILVA, 1972, p.109).

Em 1863, os primeiros imigrantes, liderados pelo colonizador Ferdinand Hackrath, decidiram subir um afluente do Rio Itajaí-Açú, o Rio do Testo, a partir do atual bairro Badenfurt. A colonização da área foi uma estratégia para fortalecer o comércio entre a Colônia de Dona Francisca, atual Joinville, e a Colônia de Blumenau. A antiga sede do distrito da Vila de Rio do Testo torna-se Pomerode, que resulta da junção da origem de seus fundadores, a Pomerânia no norte da Alemanha (Pommern),

\begin{tabular}{llllll}
\hline Caminhos de Geografia & Uberlândia - MG & v. 19, n. 67 & Set/2018 & p. 126-142 & Página 131
\end{tabular}


com o verbo rodern, que significa tirar os tocos, tornar a terra apta para o cultivo. (SC, 2010) Até a virada do século XX, Pomerode voltava-se apenas para agricultura e a pecuária de subsistência, com pequenos pontos comerciais nas áreas centrais da colônia. Com a mudança de século, pequenas empresas familiares de laticínios, frios, móveis e cerâmica deram início à industrialização do município. Apesar de ter sido desmembrada de Blumenau em 1959, Pomerode gravita em torno de sua influência, sem perder as características alemãs, porque não sofreu um significativo processo de crescimento urbano e a consequente pressão sobre o solo urbano, no sentido da renovação de seu patrimônio arquitetônico.

O processo de expansão da colonização avança do rio Itajaí-Açu em direção às margens do rio ItajaíMirim, chegando, em 1860, a Vicente Só (atual praça), onde é instalada a colônia Itajahy, atual cidade de Brusque. Novas levas migratórias vieram se somar, com a chegada de ingleses (em 1867) e poloneses (em 1869), mas a mais importante foi a vinda de 10 mil imigrantes italianos (em 1875). Os poloneses migraram, também, para outras localidades próximas, como é o caso de Indaial ou Rodeio. A chegada de italianos, além de ocupar diversas áreas já estabelecidas de colonização alemã (Blumenau, Indaial, Gaspar), iniciou outras nucleações como Rodeio ou Luís Alves que, por sua vez, também receberam alemães ou poloneses, além de outras nacionalidades minoritariamente (franceses, austríacos e belgas), dando ao Vale do Itajaí uma característica multicultural, apesar da predominância da paisagem alemã. (SEIFFERT, 1974)

No nordeste do Estado, aos primeiros alemães que vieram formar a Colônia Dona Francisca (hoje Joinville), em 1851, sucederam-se novas ocupações, organizadas pela Cia. Colonizadora de Hamburgo que, mesmo não possuindo mais terras na área, continuava com os negócios migratórios. (FICKER, 1965) Os alojados no rancho da Companhia aumentavam sem que houvesse terras para eles, obrigando-os a continuar a caminhada para áreas mais interiorizadas. Em 1873 atingiam as margens do Riacho São Bento e de lá partiram para abrir os primeiros caminhos na mata, sempre ao longo do riacho São Bento. (PIAZZA, 1982) Diversas nacionalidades compunham esses fluxos migratórios que viriam a constituir, posteriormente, uma indústria diversificada (móveis, cerâmica, plásticos, metalurgia, fiação e tecelagem), a partir de uma pequena acumulação inicial e a evolução da atividade artesanal e manufatureira.

As áreas de colonização alemã desenvolveram, rapidamente, sua vocação industrial. Os migrantes eram qualificados e conheciam de perto as lides fabris. Assim que podiam, instalavam, em suas residências, uma pequena manufatura, baseada no trabalho doméstico. Tal foi o caso da família Hering que, contando com o apoio de seus vínculos com o país de origem, montou a primeira fábrica de malhas para produzir aquela camiseta que o português tinha o hábito de trazer sob a camisa. (PIMENTA, 1994) Ainda no século XIX outras pequenas manufaturas foram montadas no interior desse Vale. (HERING, 1987) Essas fábricas, localizadas hoje nas áreas centrais de diversos municípios, deixam um legado impressionante em termos de patrimônio industrial que deveria ser restritivamente protegido. Os parques industriais que foram se constituindo representam um panorama de diferentes períodos históricos e precisariam ser cuidadosamente considerados, talvez não pela suntuosidade arquitetônica em si, mas pela variedade tipológica e a demonstração de diversas fases do desenvolvimento industrial. Relações sociais e políticas locais foram, também, cunhadas pelas atividades fabris e fazem parte da memória regional. Há que se destacar, ainda, que a implantação dessas indústrias, nos fundos dos vales, seguia modelos dos países europeus de origem, organizando, com características peculiares, a estrutura e a expansão da malha urbana. (Fig.5)

Se as cidades do Vale do Itajaí guardam fortes características alemãs, pode-se afirmar que Joinville sofreu maiores transformações urbanas, devido ao intenso processo de industrialização (CEAG/SC, 1980). O conjunto urbano tradicional cede lugar a exemplares isolados de valor patrimonial. Em Santa Catarina, grande parte dos bens arquitetônicos e das práticas sociais, que podem ser considerados resquícios históricos, localizam-se em áreas rurais ou cidades de pequeno porte. A arquitetura de origem alemã, residual ou predominante, ainda está presente em ambientes urbanos ou rurais nessas áreas de colonização, variando em função do apego e da determinação das populações locais. O Vale do Itajaí ainda é rico em exemplares patrimoniais, sendo marcado pelo enxaimel, técnica tradicional que estrutura as paredes de tijolos com entravamento de madeiras encaixadas, sem utilização de pregos. Mesmo os migrantes italianos do Vale do Itajaí produziam (alguns ainda produzem), magistralmente, a arquitetura tradicional alemã. (Fig. 6) 
Figuras 5 e 6: Ocupação industrial dos fundos dos vales e enxaimel em Blumenau

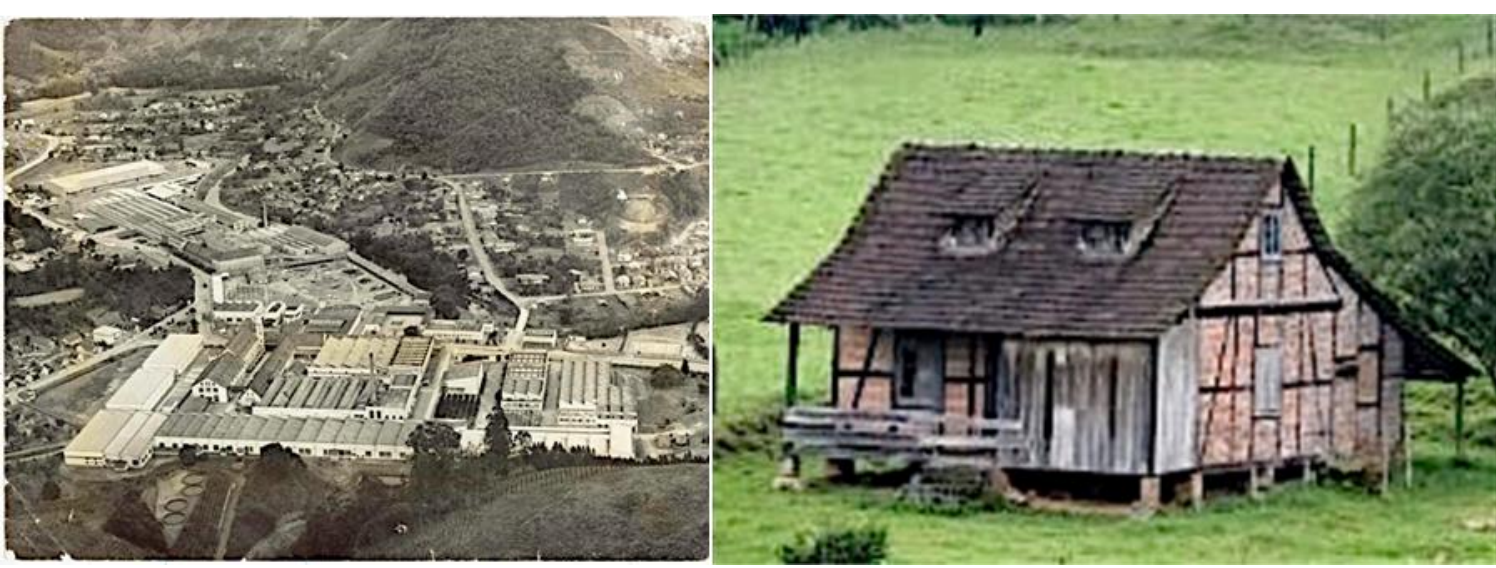

Fontes: Foto do blog de Adalberto Day. Recorte da foto de Gilmar de Souza, DC, 29/02/2016.

A característica alemã marca a arquitetura do enxaimel, mas também a forma de ocupação do espaço urbano e regional, que se estendia pelos fundos dos vales dos rios Itajaí-Açu e Itajaí-Mirim. Nas margens desses rios são abertos caminhos, que se cruzam com aqueles que chegam das florestas e que, constituirão as futuras vias principais e secundárias. Ao longo dessas trilhas são traçados, perpendicularmente, terrenos estreitos e compridos, repetindo o modelo de povoamento do final da Idade Média em algumas regiões que constituirão a Alemanha. (SILVA, 1954) O "Waldhufendorf" ("Wald" = floresta; "hufen" = pedaço estreito e alongado de terra, distribuído aos camponeses, e "dorf" = vila) retrata, claramente, a concepção da ocupação, associando trabalho agrícola e organização urbana. (SEIFFERT, 1974) O processo mais intenso de ocupação concentrava-se, na sede da colônia, a Stadtplatz. (Fig. 7) (SILVA, 1972, p. 63) Ali se desenvolvia uma rica vida cultural e associativa - com a constituição de bandas e orquestras, clubes de caça e pescas, associações diversas - em aparente dissintonia com um ambiente considerado inóspito e pouco urbanizado. (PIMENTA, 1998; KILLIAN, 1950) (Fig. 6) Chega a surpreender o fato de que, junto com os imigrantes alemães, tenha se transportado todo um estilo de vida social, mesmo em um meio ainda selvagem e pouco desenvolvido culturalmente. (Fig. 8) Constitui-se num verdadeiro transplante cultural, quando hábitos urbanos europeus passam a ser inseridos em uma estrutura rudimentar em uma área praticamente isolada, de um território nacional ainda fragmentado, com conexões internas raras e precárias. (PIMENTA, 1994)

Figura 7 e 8: Blumenau, Stadtplatz, com a escola e a igreja (1869). À direita, Clube Náutico América Regata, em 09 de outubro de 1927

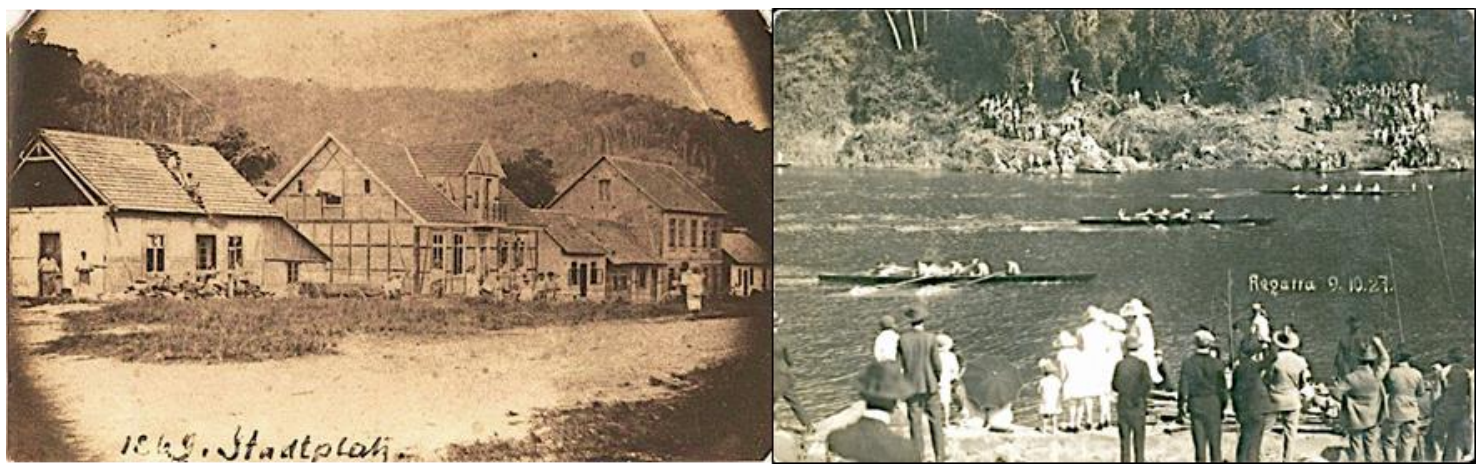

Fontes: Arquivo Municipal de Blumenau; Arquivo Histórico José Ferreira da Silva.

A influência germânica é visível na arquitetura em estilo enxaimel, facilmente identificada nos prédios com estruturas aparentes de madeira e paredes de tijolos maciços. (WAIBEL, 1979) Às heranças de traços germânicos acrescentam-se exemplares da arquitetura italiana, que ainda estão conservados, principalmente em meio rural. Se os italianos fizeram parte da ocupação do Vale do Itajaí e do

\begin{tabular}{llllll}
\hline Caminhos de Geografia & Uberlândia - MG & v. 19, n. 67 & Set/2018 & p. 126-142 & Página 133
\end{tabular}


Nordeste catarinense, certamente, sua influência foi mais decisiva em áreas onde tiveram maior predominância, como nos primeiros movimentos migratórios para o Vale do Rio Tijucas e o Sul catarinense. Nesses locais, a migração italiana marcou e definiu a cultura, as tradições e as paisagens. Muitas dessas características ainda permanecem, sobretudo no meio rural e nas pequenas cidades, tanto nas formas construídas e na organização das estruturas produtivas, como na culinária, nos costumes, nas festas.

\section{MIGRAÇÕES ITALIANAS CONFIGURAM O SUL CATARINENSE}

O Sul Catarinense é uma das mais expressivas regiões de imigração italiana em Santa Catarina. Ali a etnia italiana, oriunda principalmente do norte da Itália, foi majoritária, e a primeira a se implantar, desbravando as áreas de matas para a constituição de suas pequenas propriedades agrícolas. As colônias eram originárias da divisão da terra em lotes, que se organizavam ao longo das "linhas", como eram e são chamadas as estradas vicinais. Acompanhavam, em geral, os vales dos rios e riachos, a partir dos quais as propriedades se distribuíam, com testadas bem inferiores a suas profundidades, que adentravam as matas e recobriam o relevo.

Fundaram-se os primeiros povoadas no Vale do Rio Tubarão e seus afluentes. Os primeiros italianos estabeleceram-se na confluência do Rio Pedras Grandes, no Rio Tubarão, formando a Colônia Azambuja, em 1877, sendo o primeiro povoado da série de ocupações que a imigração realizaria na região. (PIAZZA, 1982) Os migrantes italianos foram introduzidos pelos luso-brasileiros na prática de cultivo de espécies autóctones e outras já cultivadas anteriormente, mas trouxeram em suas bagagens suas próprias tradições, como o cultivo da vinha, dando feições próprias às suas terras.

Cruzando os divisores de águas em direção às terras devolutas mais ao sul, a colonização italiana ocupou os vales do Rio Urussanga e do Rio Araranguá. Em 1878, os imigrantes fundam a Colônia Urussanga que, por muito tempo, polarizaria o interior destes vales. Em 1879, foi encaminhada para Urussanga nova leva de imigrantes, estabelecendo-se nas linhas Rio dos Bugres, Rio Maior, Urussanga Baixa, Rio América, Salto e Gaeté. (CABRAL, 1970) (Fig. 9)

Em 1882, constituiu-se a Empresa de Terras e Colonização de Grão Pará, com a finalidade de dar destinação rentável às terras do dote matrimonial do Conde D’Eu, casado com a Princesa Isabel, loteando-as e ocupando-as. Foram assentados colonos, formando as localidades de Orleans e Grão Pará. (CABRAL, 1970) Com a continuidade do fluxo de imigrantes, novas linhas e povoados, a partir de Urussanga, foram tendo seus lotes ocupados em direção ao sul e, em 1880, já havia colonos estabelecidos no atual município de Cocal e na área de Criciúma, atingindo Nova Veneza em 1891.

Figura 9 e 10: Sul catarinense: roteiro da imigração italiana e Estrada de Ferro D. Teresa Cristina.

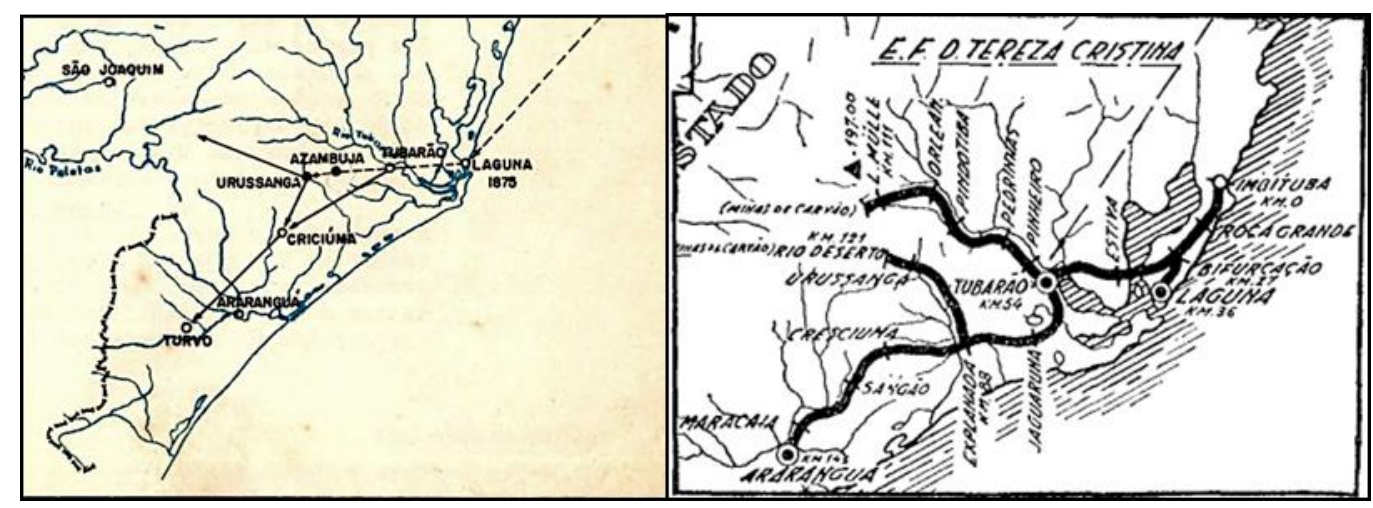

Fontes: SANTA CATARINA, 1958; Instituto Brasileiro de Geografia e Estatística (IBGE),1954.

Os primeiros anos da imigração italiana coincidem com a construção da Estrada de Ferro Dona Tereza Cristina, cujo tronco principal foi realizado entre 1880 e 1884, percorrendo os mesmos caminhos que os colonos percorriam para seu assentamento. A ferrovia foi implantada para que as minas de carvão, localizadas nas cabeceiras do Rio Tubarão, e conhecidas desde 1830, pudessem ser exploradas. Ligava, assim, a localidade conhecida por Minas (atual município de Lauro Muller) aos portos de Imbituba e Laguna. (Fig. 10) A descoberta e exploração de minas de carvão em várias

$\begin{array}{llllll}\text { Caminhos de Geografia } & \text { Uberlândia - MG } & \text { v. 19, n. } 67 & \text { Set/2018 } & \text { p. 126-142 } & \text { Página } 134\end{array}$


localidades, revelando a existência de uma bacia carbonífera de dimensões consideráveis, acelerou a economia regional, com um vigoroso processo de acumulação de capitais, que deu impulso à formação de parque industrial diversificado no século XX. Dois novos ramais ferroviários, ligavam as novas minas aos portos. O primeiro estendeu os trilhos até Criciúma (1919) e Araranguá (1927). O outro ramal ligou Urussanga à ferrovia em 1925. A descoberta de carvão no subsolo de Criciúma, por volta de 1913, e sua exploração a partir de 1916, promoveu o crescimento da cidade que tornou-se a mais populosa do Sul Catarinense. (PIAZZA, 1983)

Os imigrantes de origem italiana, em suas colônias, polarizadas por incipientes cidades, implantaram ofícios que atendiam às necessidades de reprodução da vida do mundo rural e da urbanização nascente. Trouxeram esses ofícios - a ferraria, carpintaria, marcenaria, tanoaria, entre outros - de seus países de origem, combinando-os com os trabalhos na terra. A abundância de florestas de alto porte, constituindo-se em ameaça e desafio, logo foi convertida em fonte de recursos econômicos, estabelecendo-se o beneficiamento de madeiras, primeiro a braço, em seguida com serrarias movidas a roda d'água. (Fig. 11) Os insumos encontrados pelos imigrantes - pedras, madeiras, argilas - e as técnicas trazidas em suas bagagens, traduziram-se, inicialmente, numa rústica e expressiva arquitetura, respondendo às necessidades de habitar, trabalhar a terra, cultuar suas crenças, ou seja, reproduzir sua sociedade, de forma ampliada. Para isso, erigiram casas, instalações produtivas, igrejas, capelas, oratórios, escolas e salões. Utilizando-se de pedras, taipa ou cantaria, dos tijolos que fabricavam, e da madeira encontrada, construíram um singular patrimônio edificado casas, instalações rurais e igrejas - com forte influência de sua terra de origem, constituindo uma paisagem cujo legado persiste na atualidade. (Fig. 12) Floresceram arquiteturas de pedras, alvenarias de tijolos e madeira, das quais muitos exemplares sobreviveram - apesar de desprotegidos em sua maioria -, prestando o testemunho desta cultura.

Figura 11 e 12: Colônia em Urussanga com roda d’água. Casa de pedra da família Bratti em Nova Veneza

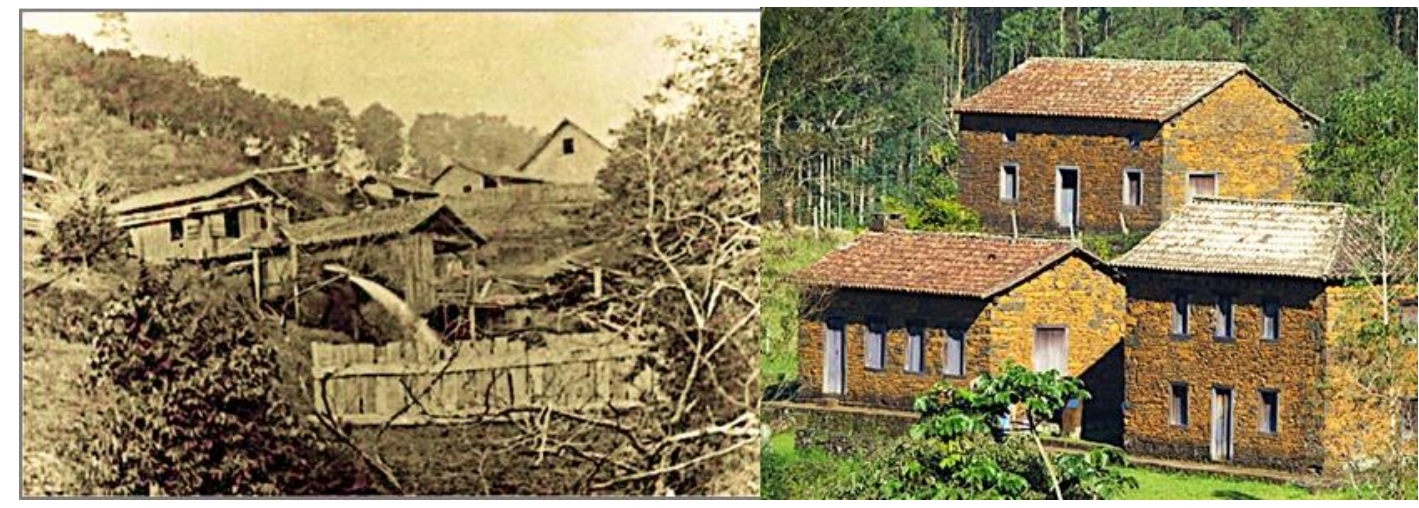

Fontes: SANTA CATARINA, 2009; MARIOT, 2014.

O desenvolvimento comercial e industrial subsequente fez com que uma arquitetura com traços de erudição - com o ecletismo na arquitetura - aparecesse nas cidades, apesar de serem ainda pequenos núcleos urbanos. Acompanhava, então, o crescimento da urbanização que se propunha a tornar visíveis os capitais acumulados. Na esteira do crescimento econômico, propiciado pela extração do carvão, diversificou-se o parque industrial com modernas fábricas, em vários ramos, destacando-se a cerâmica de revestimentos, onde a região situa-se, em meados dos anos 1990, entre as maiores produtoras do Brasil do mundo. Os descendentes de imigrantes do Sul Catarinense fizeram parte de uma próspera economia que foi impulsionada pelos vários períodos de expansão da exploração carbonífera. Suas marcas encontram-se em toda parte pelo sul catarinense, mas sobretudo na lembrança de uma sociedade de mineiros, fortemente organizados. As minas de carvão, mas também as igrejas, muito coloridas internamente, o time de futebol, as atividades de lazer, estão presentes na vontade de permanência de uma história que conformou laços de solidariedade, como somente o local pode construir e fazer lembrar, transformando-se em lugar de memória. (NORA, 1984) 


\section{O VALE do tIJUCAS E O OESTE CATARINENSE: OCUPAÇÃo E EXPANSÃo dAS CORRENTES ITALIANAS}

A imigração italiana expressou-se também, de forma decisiva, em outras regiões do Estado de Santa Catarina, como fluxo direto europeu, mas também, num segundo momento, com migrantes de segunda geração vindos do Rio Grande do Sul, que ocuparam o meio-oeste (Vale do Rio do Peixe) e oeste catarinenses. No Vale do Itajaí, continuou a marcha de ocupação iniciada pelos alemães, a partir de 1875.

A cultura italiana expressou-se com menor intensidade nos centros maiores, já marcados pela etnia teuto-brasileira, singularizando-se, no entanto, nos povoados em que foram predominantes. Ultrapassando o Vale do Itajaí Mirim, as levas de italianos foram assentadas no Vale do Rio Tijucas, desde 1875. Até 1880 estima-se que 11000 colonos entraram nas linhas de Tijucas. (CABRAL, 1970). Ligadas às rotas comerciais pelo porto de Tijucas, na desembocadura do rio, as economias das colônias prosperaram com a extração da madeira e a implantação de engenhos em grande número, dispostos pelas pequenas propriedades rurais. Os engenhos e serrarias movidos a roda d'água perduraram até a década de 1970, quando se completa a eletrificação rural. Encontram-se exemplares de engenhos ainda em atividade, assim como velhos mestres carpinteiros construtores de engenhos, capazes de dar manutenção aos engenhos existentes e a relatar, com precisão de detalhes, o processo de feitura das suas partes e de sua montagem. (Fig.13 e 14) Reconhece-se, até o momento o Vale do Tijucas como fornecedor de mão-de-obra da mais alta qualidade para a construção civil, sendo procurada por empreiteiros dos mais diversos lugares do estado de Santa Catarina. Pode-se, também, hoje, constatar o grande número de cerâmicas, que se espalham ao longo do Rio Tijucas, interior adentro, produzindo, principalmente, telhas, mas também tijolos. É como se a qualidade técnica desses trabalhadores impregnasse o espaço, de forma resistente, podendo-se representar o Vale por suas práticas e habilidades.

Figura 13 e 14: Nova Trento, engenho de farinha. Herval d'Oeste, Sede Belém: casa e paiol.

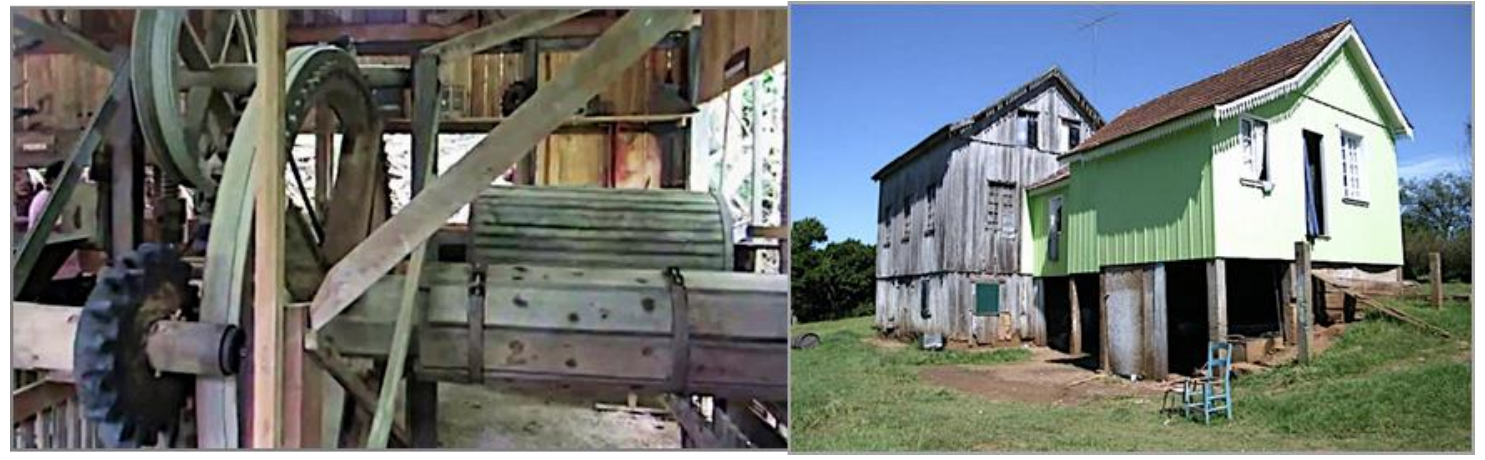

Fontes: Museu da Cultura Italiana; foto do autor, 2010.

Nova Trento, incrustada nos vales do rio do Braço e seus afluentes, é a mais tradicional das ocupações de ítalo-brasileiros do Vale do Tijucas. Ficou conhecida pela habilidade de seus pedreiros, descendentes de italianos, que aliando maestria construtiva e religiosidade, tornaram-se importantes construtores para a organização religiosa católica, edificando igrejas, seminários e conventos, disseminados pelo interior do Estado. (Fig. 15 e 16)

As igrejas de origem italiana são ricas em detalhes multicoloridos. (Fig.16) Tanto no Vale do Tijucas como no sul catarinense, encontram-se diversos exemplares, muito bem conservados, devido aos recursos dos próprios moradores que financiavam as pinturas que eram realizadas. As famílias locais, de forte apego religioso, dividiam os espaços internos das igrejas para cunhar suas doações artísticas. Seus herdeiros atuais reconhecem e valorizam os registros deixados pelos antepassados. Sentem-se continuadores de uma tradição, o que provoca um sentimento de proteção patrimonial bastante peculiar. A pintura um tanto atípica no que concerne a arquitetura religiosa no Brasil, em tons vibrantes, constitui-se, também, em elemento de distinção e singularidade cultural, motivo de certo orgulho identitário, demonstrado em várias ocasiões. 
Figura 15 e 16: Vale do Tijucas: Canelinha(bairro Índia), capelinha de 1915; Nova Trento, antiga igreja de Vígolo, local onde está situado o Santuário Madre Paulina

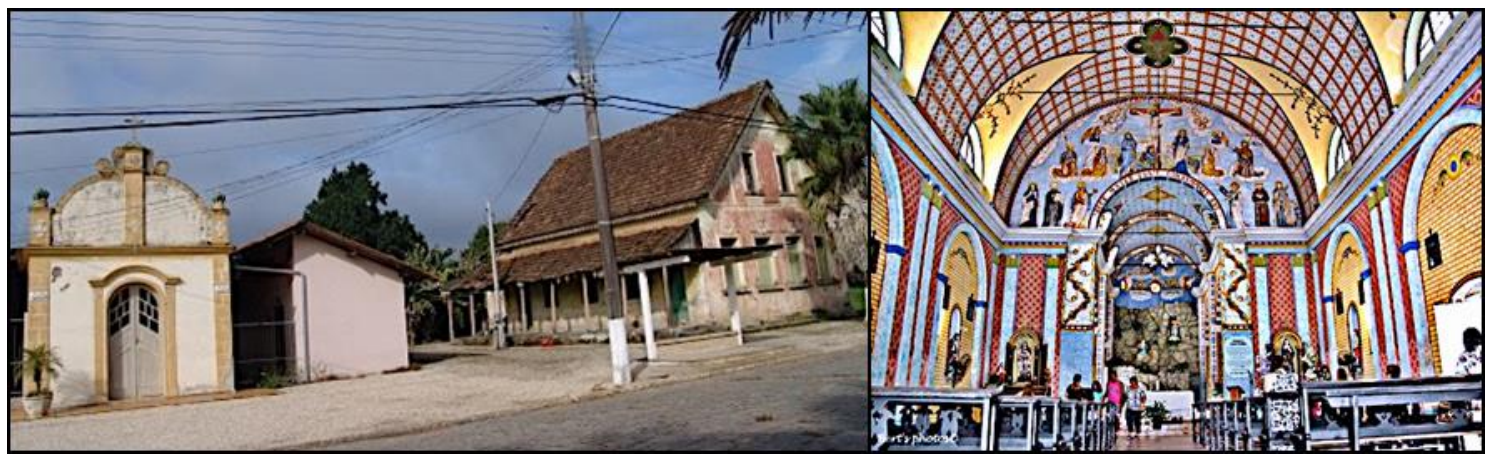

Fontes: HOROSTECKI, 2016; BERTI, 2017.

No Oeste Catarinense a presença dos descendentes de italianos foi majoritária na formação da população. Entretanto, as levas migratórias eram constituídas por excedentes populacionais das colônias do Rio Grande do Sul, que haviam se constituído no último quarto do século XIX, da mesma forma como as colônias dos vales das vertentes atlânticas de Santa Catarina. Além de descendentes de italianos, os excedentes populacionais de outras colônias velhas, principalmente alemãs, também seguiram na frente pioneira que ocupava o Oeste Catarinense.

O Vale do rio do Peixe foi a primeira região em que a frente migratória instalou-se, acompanhando a implantação da Estrada de Ferro São Paulo-Rio Grande (1910) em seu trecho catarinense. Mas sua ocupação só pôde efetivar-se após o fim da Guerra do Contestado e dos conflitos de limites entre Paraná e Santa Catarina em 1916. (PIMENTA, 1984; QUEIROZ, 1966) A continuidade do fluxo de migrantes provoca o deslocamento da demarcação e venda de lotes, por companhias colonizadoras, em direção ao extremo oeste do Estado, abrindo povoados até a metade do século XX. (PIMENTA, 1996)

A expressão arquitetônica destas migrações do século $X X$ utiliza-se principalmente da madeira em suas primeiras décadas, acompanhando a atividade econômica das serrarias na derrubada das matas. (Fig. 17 e 18) O pinheiro de araucária foi muito usado, além de madeiras "de lei" como a canela e a peroba. Casas, sobrados, igrejas, instalações industriais, estações ferroviárias, assim como grandes moinhos, marcaram a paisagem do Oeste Catarinense.

Figura 17 e 18: Ibicaré, armazém e residência em construção de madeira. Caçador, estação ferroviária (1910)

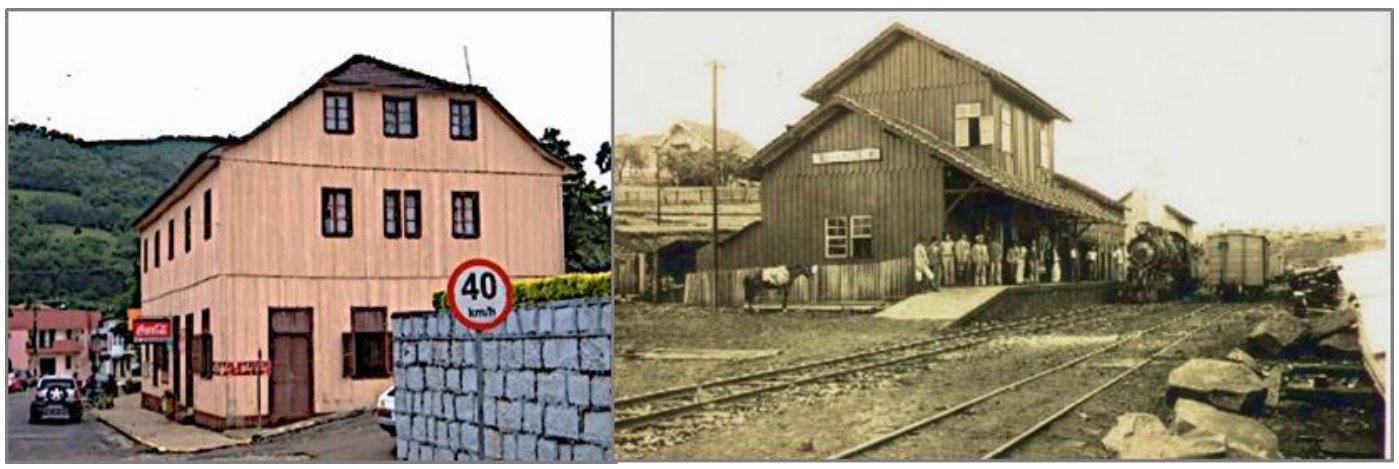

Fontes: Foto da autora, 2010. WISCHRAL, 1935. 


\section{MÚLTIPLAS NACIONALIDADES EM UM SÓ ESTADO}

A população do estado de Santa Catarina é formada por muitas etnias, sendo predominantes, mas não exclusivos, os descendentes de italianos, portugueses e alemães. Em menor medida, tem-se eslavos - poloneses e ucranianos -, austríacos, latino-americanos e outras nacionalidades que se condensam na maior parte da população branca $(85,7 \%)$, sendo pequena a porcentagem de descendentes de africanos ( $11,7 \%$ de pardos, $2,2 \%$ de negros) e ínfima a participação dos índios $(0,3 \%)$. (IBGE, 2010, p. 232.) Se é possível encontrar dominâncias em algumas áreas, houve, certamente misturas significativas nas paisagens de diversas regiões catarinenses.

Em muitas áreas do Estado pode-se perceber traços dessas heranças culturais minoritárias, como por exemplo, os exemplares arquitetônicos eslavos que marcaram a paisagem com suas construções em madeira coloridas e enfeitadas pelos arremates dos telhados em lambrequins. (Fig. 19) Herança marcante são as igrejas, como a de Santo Estanilau (polonesa) e a Sagrada Família (ucraniana) na cidade de Itaiópolis, que se compõem de uma variedade de outras etnias (inglesa, polonesa, russa e alemã). O Planalto norte é bem ilustrativo dessa mistura populacional, com várias cidades com predominância alemã, mas também com forte combinação de migrações de diferentes nacionalidades.

Figura 19 e 20: Itaiópolis. Casa Jakubiak. Residência de Andreas Thaler, fundador da Colônia de Treze Tílias, hoje Museu da Cidade

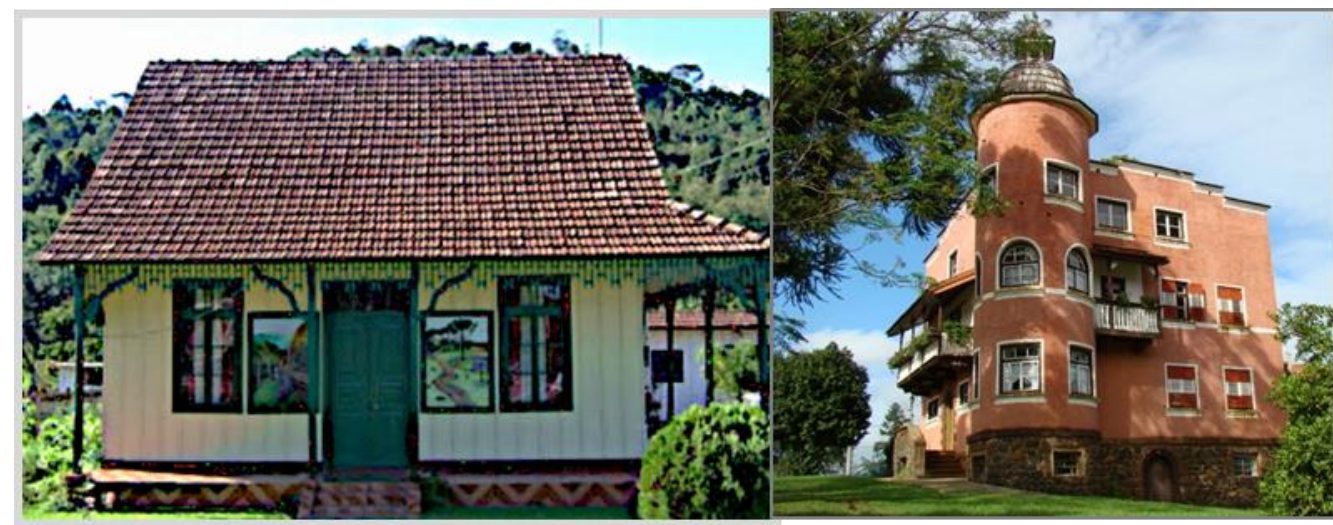

Fontes: Prefeitura Municipal de Itaiópolis; Foto do autor, 2010.

Se os austríacos são minoritários em nível do Estado, eles certamente imprimiram o caráter dominante na cidade de Treze Tílias que, apesar de ter recebido também grande número de migrantes italianos, caracteriza-se pelo estilo tirolês da arquitetura que compõe o espaço urbano. Fundada por austríacos vindos do Tirol, Treze Tílias resolveu reavivar, a partir da decisão consciente de seus habitantes, o estilo originário como marca característica da cidade. (Fig. 20) Assim, aos exemplares históricos juntam-se, agora, novas construções que visam formar um cenário urbano harmonioso e homogêneo, destacando os traços culturais da relação entre o Tirol e os imigrantes que vieram colonizar essas terras inóspitas do Meio-Oeste Catarinense.

\section{ALGUMAS CONSIDERAÇÕES FINAIS}

Santa Catarina possuía, até pouco tempo, um número quase insignificante de imóveis documentados e tombados pelos Institutos de Preservação Patrimonial em suas diferentes escalas (Federal, Estadual, Municipal). O IPHAN tinha registrado 21 bens tombados (entre eles, seis fortalezas), sendo 12 em Florianópolis (cinco fortalezas). Acrescentando-se dois sítios tombados pelo Programa Monumenta, os centros históricos de Laguna (1985) e de São Francisco do Sul (1987), tinha-se a gama de bens tombados em nível federal. (IPHAN, 2010) Após esse período, Santa Catarina é alvo de atenção e, em 2007, cerca de 60 tombamentos são realizados, sendo a maior parte em Pomerode (13), Blumenau (11), Timbó, Indaial, São Bento do Sul, Itaiópolis, Jaraguá do Sul e Joinville. (IPHAN, 2017) A proposta dos roteiros de imigração, elaborada em nível estadual (SANTA CATARINA,2017), e adotada posteriormente pelo IPHAN, foi a responsável pela preservação dessa leva de imóveis e conjuntos urbanos em 2007, incluindo o patrimônio rural, até então esquecido. No entanto, apesar da

\begin{tabular}{llllll}
\hline Caminhos de Geografia & Uberlândia - MG & v. 19, n. 67 & Set/2018 & p. 126-142 & Página 138
\end{tabular}


importância dessa proteção, que pode garantir a permanência de um patrimônio de grande valor arquitetônico, como residências, escolas, casas comerciais, igrejas e hospitais dos primeiros imigrantes, não houve a apreciação do reconhecimento dos Núcleos rurais de Testo Alto (Pomerode) e Rio da Luz (Jaraguá do Sul) como paisagem cultural, tendo sido adiada até que a matéria fosse "devidamente regulamentada". (IPHAN, 2007) Em 2011, o assunto é retomado para complementação e para "abertura de procedimento específico para concessão de chancela de Paisagem Cultural a todas as Edificações e Núcleos Urbanos relacionados com a Imigração de Santa Catarina". (IPHAN, 2011 , p. 23) Mesmo sendo considerada a justeza do pedido de reconhecimento, nota-se que são propriedades isoladas e o seu entorno, o que é bastante relevante, mas sem alcançar uma escala que respondesse à proteção inclusiva do ambiente e de sua população local. São "13 imóveis em seis cidades de Santa Catarina que formam os roteiros de colonização percorridos por alemães, italianos, poloneses e ucranianos na região Sul a partir do século 19". (BRASIL, 2011) Após 2007, as poucas propostas de novos tombamentos federais para Santa Catarina estão "em instrução", exceção feita ao acervo do Museu do Mar em São Francisco do Sul, tombado em 2010. Até aqui, ainda há a predominância quase absoluta da preservação dos imóveis sobre as paisagens, sem a atenção à proteção conjunta das práticas tradicionais em seu ambiente.

Grande parte do patrimônio em Santa Catarina foi tombada pelo Governo Estadual (Fundação Catarinense de Cultura), principalmente na década de 1990 até o ano 2000, sendo que, neste caso, Blumenau (inclui o complexo industrial Hering) e Joinville são as cidades que possuem o maior número de bens tombados (cerca de 40 bens tombados), seguidas de Urussanga (com 24 imóveis, sendo a maior parte em uma mesma praça) e Florianópolis e Lages (18 bens tombados), Pomerode (14), Itajaí (13). (SANTA CATARINA, 2017b) O acervo é constituído, principalmente, de antigas residências que adquiriram, ou não, novas funções, igrejas e casas paroquiais, um ou outro palácio, grupo escolar ou comércio. Nas outras cidades que possuem bens tombados, a quantidade varia de um a três imóveis. Pode-se observar ainda que, dos 295 municípios de Santa Catarina, somente cerca de 40 possuem bens tombados, considerando as duas instâncias governamentais, federal e estadual. (IPHAN, 2017)

Em nível municipal, a proteção deixa muito a desejar na maioria das cidades. Em Florianópolis, por exemplo, na quase totalidade dos imóveis do centro, a preservação ficou quase totalmente restrita às fachadas dos imóveis, com uma visão cenográfica do acervo histórico. Não se trata aqui de uma extensa área, como no Rio de Janeiro, São Paulo ou as cidades históricas mineiras, mas de uma estrutura urbana reticulada, composta de menos de uma dezena de quadras que constituem o centro histórico, o que torna o baixo nível de proteção totalmente injustificável. Importante ainda destacar que a realidade ultrapassou largamente as intenções municipais, e as fachadas foram totalmente adulteradas, indo além da destruição sistemática de todo o interior do conjunto arquitetônico, o que havia sido recomendado pela cartilha elaborada pelos próprios órgãos municipais, que deveriam ter sido os responsáveis diretos por essa preservação. (IPUF, 1993) A irreversibilidade de tais decisões certamente não foi considerada. Hoje, os imóveis estão todos desfigurados, sem retornos possíveis.

Apesar desses procedimentos de formalização, o estado de conservação dos bens nem sempre condiz com a condição de reconhecimento de seu valor patrimonial. Nem mesmo o entorno dessas edificações ou os conjuntos edificados permitem, na maior parte dos casos, o destaque enquanto 'lugares de memória' que precisariam ser alicerçados na memória social. Para isso, far-se-ia necessário que se tornassem lugares impregnados de vontade de memória (NORA, 1984) Contrariamente aos países europeus, os conjuntos rurais ou urbanos preservados fazem exceção. A política de preservação de paisagens culturais, compreendidas com o sentido atribuído pela UNESCO de "obras combinadas da natureza e dos homens", é praticamente inexistente. Considerando as dificuldades desse tipo de preservação em meio urbano, uma atenção maior deveria ser dada às pequenas e médias cidades, assim como à manutenção dos pequenos proprietários rurais junto com a sua herança materializada.

As resistências que se encontram em relação à ampliação da escala de tombamento referem-se, principalmente, à subordinação das instâncias decisórias a interesses corporativos. (SANTOS, 2000) O patrimônio e as paisagens históricas encontram-se, em geral, em áreas hoje muito bem localizadas, decorrente da própria expansão dos processos ocupacionais. Pelo fato mesmo de estarem ameaçadas enquanto lugar integrativo entre ambiente e comunidades tradicionais, precisam da proteção mais efetiva e de políticas de incentivo à permanência dessas populações e seus modos de vida e à recuperação dos bens patrimoniais.

A arquitetura institucional, religiosa, industrial, habitacional, assim como os planos urbanos e a evolução das ideias urbanísticas podem ser objeto desta identificação como constituintes da

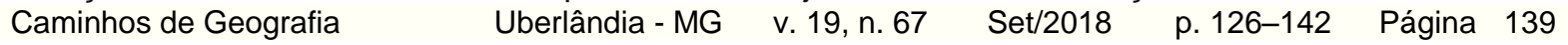


caracterização das diversas paisagens culturais. Partindo da análise histórica, essa seria a metodologia aqui proposta para se pensar a preservação paisagística. Também seria um caminho para se evitar as deformações oriundas das novas propostas mercantis que associam turismo e folclorização dos bens e práticas patrimoniais. Os monumentos isolados passariam a ser analisados como componentes da conformação espacial, oriundos do fabrico humano. (SANTOS, 1988) A intervenção do homem na transformação constante da natureza vem agregar um sentido dinâmico à ideia de bem patrimonial. Mudar não significa, necessariamente, renovar tudo, partir sem história, mas fazer parte da construção de um fio temporal, com continuidades e rupturas (VEYNE,1998), sem nos prender ao passado, mas convivendo com sua presença, no sentido de construir perspectivas humanizadas.

\section{REFERÊNCIAS}

ARENDT, Hanna. La condición humana. Buenos Aires: Paidós. 2009.

BABELON, J.-P.; CHASTEL, André. La notion de Patrimoine. Paris: Editions Liana Levi, 1994.

BOUDEVILLE, J.R. Aménagement du Territoire et Polarisation. Paris: Génin et Librairies Techniques, 1963.

BRASIL. Santa Catarina recebe primeiro tombamento definitivo de paisagem cultural brasileira. Disponível em: http://www.brasil.gov.br/. Acesso em: 24 de maio de 2012.

BROOS, Hans. Construções antigas em Santa Catarina. Florianópolis: Editora da UFSC, 2002.

CABRAL, Oswaldo Rodrigues. Nossa Senhora do Desterro. Florianópolis: Imprensa da UFSC, 1972.

CABRAL, Oswaldo Rodrigues. História de Santa Catarina. Florianópolis: Landes, 1970.

CASSIRER, Ernst. Filosofías de las formas simbólicas. Tomo 1. México: Fondo de Cultura Económica, 1998.

CEAG/SC. Centro de Apoio à Média e Pequena Empresa de Santa Catarina. Evolução Históricoeconômica de Santa Catarina. Estudo das alterações estruturais (século XIX-1960). Florianópolis: CEAG/SC, 1980.

CLAVAL, Paul. Geografia Cultural. Tradução de Margareth de Castro Afeche Pimenta e Luís Fugazzola Pimenta. Florianópolis: Editora da UFSC, 1999.

FICKER, Carlos. História de Joinville. Brasília: Ipiranga, 1965.

FOUQUET, Carlos. Vida e Obra do Dr. Blumenau. Ensaio Biográfico. In Centenário de Blumenau 1850-1950. Blumenau: Comissão de Festejos, Tip. Blumenauense, 1950, p.52-115.

GOETHE, Johann Wolfgang von. Mélanges. CEuvres Complètes. Tome X. Tradução de Jacques Porchat. Paris: Hachette, 1863.

HERING, M. Luiza R. Colonização e Indústria no Vale do Itajaí. Blumenau: Editora da FURB, 1987.

IBGE. Instituto Brasileiro de Geografia e Estatística. Síntese de Indicadores Sociais 2010. Uma análise das condições de vida da população brasileira. Estudos e Pesquisas. Informação demográfica e socioeconômica, 27 Rio de Janeiro, IBGE, 2010. Disponível em: biblioteca.ibge.gov.br/visualizacao/livros/liv45700.pdf Acesso em: 19 de setembro de 2010.

IPHAN. - Instituto de Patrimônio Histórico e Artístico Nacional. Guia de bens tombados. Santa Catarina, 2009. Disponível em: www.iphan.gov.br Acesso em: outubro 2010.

Patrimônio Material - SANTA CATARINA. Disponível em: www.portal.iphan.gov.br. Acesso em: 9 de agosto de 2017.

Ata da 55 Reunião do Conselho Consultivo do Patrimônio Cultural, realizada em 6 de dezembro de 2007. Disponível em: www.portal.iphan.gov.br. Acesso em: 9 de agosto de 2017.

Ata da 67 Reunião do Conselho Consultivo do Patrimônio Cultural, realizada em 3 de maio de 2011. Disponível em: www.portal.iphan.gov.br. Acesso em: 9 de agosto de 2017.

IPUF - Instituto de Planejamento Urbano de Florianópolis. Projeto Renovar. Valorização do casario histórico de Florianópolis. Florianópolis: IPUF, 1993.

\begin{tabular}{llllll}
\hline Caminhos de Geografia & Uberlândia - MG & v. 19, n. 67 & Set/2018 & p. 126-142 & Página 140
\end{tabular}


JEUDY, Henri-Pierre. Memória do social. Rio de Janeiro: Forense Universitária, 1990.

KILIAN, Frederico. Sociedades e Associações em Blumenau. In Centenário de Blumenau 18501950. Blumenau, Comissão de Festejos, Tip. Blumenauense, 1950, p.338-345.

LEFEBVRE, Henri. La production de l'espace. Paris: Éditions Anthropos,1974.

LOCKS, Geraldo Augusto et al. Caminho das tropas: caminhos, pousos e passos em Santa Catarina. Lages: UNIPLAC / SEBRAE, 2006.

MARX, Karl. Contribuição à Crítica da Economia Política. São Paulo: Editora Expressão Popular, 2007.

NORA, Pierre. Entre mémoire et histoire: la problématique des lieux. In NORA, Pierre (Coord.) Les lieux de mémoire. Vol 1. La République. Paris: Gallimard, 1984, p. VII-XLII.

PELUSO JR., Victor A. Tradição e Plano Urbano. Cidades portuguesas e alemães no Estado de Santa Catarina. In Estudos de Geografia Urbana de Santa Catarina. Florianópolis: Ed. da UFSC/ Secretaria do Estado de Cultura e do Esporte, 1991, p. 355-396.

A Bacia do Itajaí. In. Centenário de Blumenau 1850-1950. Blumenau: Comissão de Festejos, Tip. Blumenauense, 1950, p.116-126.

PIAZZA, Walter. A colonização de Santa Catarina. Porto Alegre: BRDE, 1982.

Santa Catarina: sua história. Florianópolis: UFSC: Lunardelli, 1983.

PIMENTA, Margareth de Castro Afeche. A paisagem cultural: multiplicidade interpretativa e políticas de preservação. Ateliê Geográfico. Goiânia-GO, v. 10, n. 2, p. 97-114, agosto/2016. Disponível em: https://www.revistas.ufg.br/atelie/article/view/38054

Paisagens culturais: fragilidades de presenças imprescindíveis. Cadernos de Arquitetura e Urbanismo, v.22, n.31, p. 9-25, $2015 . \quad$ Disponível em: http:// http://periodicos.pucminas.br/index.php/Arquiteturaeurbanismo/

Turismo e paisagens históricas nas vilas litorâneas catarinenses. In PIMENTA, Margareth de Castro Afeche; FIGUEIREDO, Lauro César (Coord.) Lugares: patrimônio, memória e paisagens. Florianópolis: Editora da UFSC, 2014, p. 205-234.

. Industrialisation et territoire: le cas de l'industrie textile et de la confection au Brésil (1850-1980). Tese (Doutorado em Geografia) - Paris: Universidade de Paris IV - Sorbonne, 1994.

Cultura teuto-brasileira e a cidade industrial de Blumenau em Santa Catarina. Revista Dynamis. Blumenau: Editora da FURB, v.6, n.24, p. 62-83, Julho-Setembro 1998.

PIMENTA, Margareth de Castro Afeche et al. Mestres Artífices de Santa Catarina. Brasília: IPHAN, 2012.

PIMENTA, Luís Fugazzola. Cidades pioneiras: identidade e modernização no Oeste de Santa Catarina. In PINHEIRO MACHADO, Denise (Coord.). IV Seminário de história da cidade e do urbanismo. Rio de Janeiro, Anais... RJ:PROURB, p 285-292, 1996.

QUEIROZ, Maurício Vinhas de. Messianismo e Conflito Social - A Guerra Sertaneja do Contestado: 1912/1916. Rio de Janeiro: Civilização Brasileira, 1966.

REIS FILHO, Nestor Goulart. Contribuição ao Estudo da Evolução Urbana do Brasil (1500-1720). São Paulo: Pioneira, 1968.

SANTA CATARINA. Roteiros Nacionais de Imigração. Disponível em: http://www.fcc.sc.gov.br. Acesso em: 20 de junho de 2017.

Relação de Bens Tombados do Estado de Santa Catarina. Fundação Catarinense de Cultura. Disponível em: www.fcc.sc.gov.br. Acesso em: 8 de agosto de 2017b.

História de Pomerode. Prefeitura Municipal de Pomerode. Disponível em: http://www.pomerode.sc.gov.br/. Acesso em: 10 de outubro 2010.

Departamento Estadual de Geografia e Cartografia. Atlas geográfico de Santa Catarina. Florianópolis: DEGC/SC, 1958. 
SANTOS, Milton. Por uma outra globalização: do pensamento único à consciência universal. Rio de Janeiro: Record, 2000.

A natureza do espaço. São Paulo: Hucitec, 1996.

As metamorfoses do espaço habitado. São Paulo: Hucitec, 1988.

Espaço e método. São Paulo: Nobel, 1985.

SEIFERTH, Giralda. A colonização alemã no Vale do Itajaí-Mirim. Porto Alegre: Editora Movimento, 1974.

SILVA, José Ferreira. História de Blumenau. Florianópolis: Edeme, 1972.

SILVA, Zedar Perfeito da. O Vale do Itajaí. Rio de Janeiro: Ministério da Agricultura, Serviço de Informação Agrícola, 1954.

UNESCO. Patrimônio Mundial. Tese Disponível em: whc.unesco.org. Acesso em: 11 de outubro de 2010.

VEBLEN, Thorstein. Théorie de la classe de loisir. Paris: Gallimard, 1978.

VEYNE, Paul. Como se escreve a história. Brasília: Editora Universidade de Brasília, 1998.

WAIBEL, Leo. Capítulos de Geografia Tropical e do Brasil. Rio de Janeiro: IBGE, 1979.

WILLEMS, Emilio. A aculturação dos alemães no Brasil. São Paulo: Ed. Nacional; Brasília: INL, 1980.

Recebido em: 03/09/2017

Aceito para publicação em: 05/09/2018 